\title{
COMPARATIVE BIO-RESIDUAL ACTIVITY OF PYRIDALYL AND METHOMY INSECTICIDES AGAINST LARVAE OF THE COTTON LEAFWORM, SPODOPTERA LITTORALIS(BOISD.)
}

\author{
ABDEL-RAHIM, ELHAM F. M. \\ Sides Agric. Res. Station, Plant Protection Res. Institute, ARC, Dokie, Giza
}

(Manuscript received 4 July 2010 )

\begin{abstract}
The bio-residual activity of two compounds, pyridalyl and methomyl against the second and fourth instar larvae of laboratory strain of the cotton leafworm, Spodoptera littoralis was evaluated under laboratory and semi-field conditions. The obtained larvae were fed for $48 \mathrm{~h}$ on cotton leaves treated with the two compounds at $0,3,7$ and 12 days after the treatment. To study two tested compounds had a similar effect on the $2^{\text {nd }}$ and $4^{\text {th }}$ instar larvae at 0 and 3days of the treatment. The second instar larvae were more susceptible to the two insecticides than the fourth ones. At leaf residues aged 7 and 12days, methomyl treatments had the greatest residual effect than that of pyridalyl. Pyridalyl and methomyl treatments had a latent effect on the. biological activities of this insect when the larvae fed on the leaf residues aged 12days. The effect was varied according to the larval instar and tested compound. It was found that the $2^{\text {nd }}$ instar larvae treated with both pyridalyl and methomyl or the $4^{\text {th }}$ instar larvae treated with methomyl highly significantly increased the larval duration. Also, the larval treatment of both instars with the two compounds caused highly significant increase on the pupal duration. Pyridalyl and methomyl caused highly significant decrease on the pupal weigh and adult emergence, and pyridalyl treatment had the highest effect in this respect. While, the larval treatment of the second and fourth instar with methomyl and the $2^{\text {nd }}$ instar treated with pyridalyl had the strongest increasing effect on pupal and adult malformation percentages. On the other hand, the $2^{\text {nd }}$ instar treated with methomyl had the most potent in depression of both the total no. of eggs laid per female and eggs hatching to reach zero compared to $508 \mathrm{eggs} / \mathrm{f}$ and $100 \%$ that of control. While, the larval treatment of $2^{\text {nd }}$ and $4^{\text {th }}$ instar larvae with Pyridalyl inhibited the total no. of laid eggs to average 57 and 81 eggs/f . Hence only ,the $4^{\text {th }}$ instar treated with Pyridalyl reduced the eggs hatching percentage to $30 \%$.Also, the larval treatment of $4^{\text {th }}$ instar with both Pyridalyl and Methomyl highly significant decreased the adult longevity. Sex's ratio of adult males and females violent affect with the larval treatment of $2^{\text {nd }}$ and $4^{\text {th }}$ instar with methomyl and with the treated $4^{\text {th }}$ instar with Pyridalyl, where it lead to adult male percentage decrease and female percentage increase, as compared to that of control. While, the larval treatment of $2^{\text {nd }}$ instar with Pyridalyl had adversely effect in adult male percentages increase and females decrease in relative to that of control.
\end{abstract}




\section{INTRODUCTION}

The cotton leafworm, Spodoptera littoralis (Boisd) is one of the major pests that cause a considerable damage to many of the important vegetables and field crops in Egypt .The rising consumption of currently used insecticides in developing countries has led to a number of problems such as insect resistance, environmental pollution and the health hazards associated with pesticide residues. It is therefore necessary to complement our reliance on synthetic pesticides with less hazardous, safe, and biodegradable substitutes. Pyridalyl is an insecticide of a novel chemical class (unclassified) with an unknown mode of action that causes loss of vigour and death within 2-3 hours in lepidopterous larvae and is effective in the control of lepidopterous pests and thrips in cotton and vegetables. Toxicity of pyridalyl to insect pest specie, Spodoptera litura, was evaluated in the laboratory (Shigeru et al., 2004 and Isayama et al., 2005). It active against the resistant strain of diamondback, Plutella xylostella $(\mathrm{L})$ and Heliothis virescens $(\mathrm{F})$ that are resistant to various insecticides. It also produces unique insecticidal symptoms, so it may have a different mode of action from other existing insecticides.

The conventional insecticide, Methomyl was used for the lepidopterous pests control (Kassem et al., 1986).

Therefore, the present study was conducted to compare the bio- residual activity of two compounds, pyridalyl and methomyl against the second and fourth instar larvae of Spodoptera littoralis under laboratory and semi-field conditions.

\section{MATERIALS AND METHODS}

\section{The laboratory strain}

The cotton leaf worm, $S$. littoralis was reared in the laboratory for several generations at room temp. ranged between $25-28 C^{\circ}$ and $60-65 \%$ R.H. Larvae were fed on castor bean leaves, Ricinus communis (L.) in a wide glass jars until pupation and adults emergence. The newly emerged adults were mated inside glass jars and supplied with a piece of cotton wetted with $10 \%$ sugar solution as feeding source for the emerged moths and branches of Tafla (Nerium oleander L.) or castor bean leaves as an oviposition site (El- Defrawi et al.,1964 and Mohamed et al.,2000). Egg masses were kept in plastic jars until hatching. The obtained second and fourth instar larvae were used for bioassay tests.

\section{2-Insecticides used}

\section{1- Pyridalyl}


Trade name: The insecticide was introduced by Valent USA for control Lepidopterous pests in cotton under the code (S-1812). The rate of application was 50$200 \mathrm{~g}$ ai/ha.

Chemical name: 2, 6-Dichloro-4-(3, 3-dichloroallyloxy)phenyl3[5(trifluoromethyl)

2-pyridyloxy] propyl ether

Molecular Formula: $\mathrm{C} 18$ H14 Cl4 F3 NO3

Molecular Weight: 491.12

Structure:

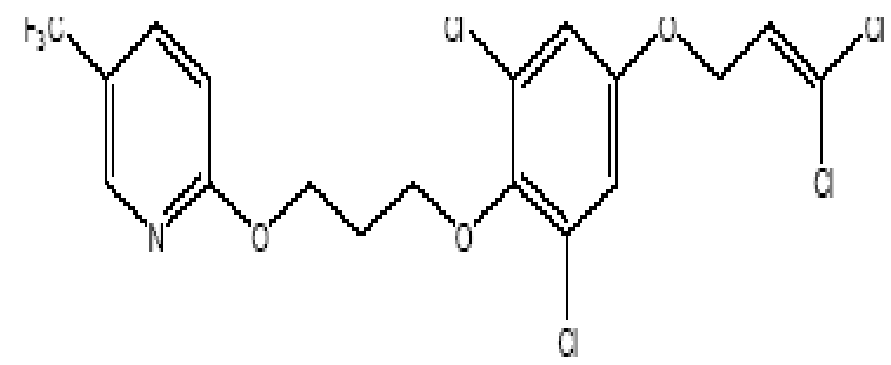

\section{2- Methomyl}

Trade names: Lannate, Lanox 216, NuBait II, Nudrin, SD 14999

Chemical Name: S-Methyl-N-[(methylcarbamoyl) oxy]-thioacetimidate

Molecular formula: $\mathrm{C} 5 \mathrm{H} 10 \mathrm{~N} 2 \mathrm{O} 2 \mathrm{~S}$

Molecular weight: 162.20

\section{Structure:}<smiles>CNC(=O)Oc1cccc2ccccc12</smiles>

\section{3- Laboratory and Semi-field tests}

The present study was carried out in an isolated region within the Sids Station Farm, Beni -Suef .The planting of cotton plant was done using large pots $(35 \times 37 \mathrm{~cm})$ under field conditions.The two compounds were sprayed at the recommended rates via a simple hand atomizer in small prepared concentrations at $1.5 \mathrm{gm} /$ litre for 
methomyl and $0.03 \mathrm{gm} /$ litre for pyridalyl (the concentrations caused $95 \%$ larval mortality of both instars treated with both compounds) .Ten replicates of pots were used in each treatment. The sprayed cotton leaves were random selected among the various replicates of the two treatments at zero, 3, 7 and 12 days of the treatment. Hundred larvae of either $2^{\text {nd }}$ or $4^{\text {th }}$ instar for larval feeding on treated leaves of the two tested compounds at the four time intervals used for $48 \mathrm{~h}$. The total percent of the larval mortality after $48 \mathrm{~h}$ of the larval feeding on the leaf residues of the two compounds were recorded and corrected according to Abbott formula (Abbott, 1925). The different biological effects such larval and pupal duration, pupation and adult emergence percentage , adult fecundity ,eggs hatching\% , adult longevity ,sex ratio\% were estimated at the leaf residues aged $12 \mathrm{~d}$ of the treatment. Also, the observed malformations were recorded and photographed. The residual effect of the tested two compounds was tabulated and diagram illustrated.

\section{4- Statistical analysis}

The data of the biology were statically calculated through Excel for windows computer program to determine the F-value, P-value and L.S.D (least significant difference at 0.05 or 0.01 freedom degrees).

\section{RESULTS AND DISCUSSION}

\section{1- Bio-residual activities}

Data presented in Table(1) demonstrated that the two tested compounds, pyridalyl and methomyl were effective against the $2^{\text {nd }}$ and $4^{\text {th }}$ instar larvae of $S$. littoralis extend to 12 days of the treatment. At the four tested leaf residues $(0,3,7$ and $12 \mathrm{~d}$. of the treatment), the second instar larvae were more susceptible for the treatments than the fourth ones. Both compounds pyridalyl and methomyl had the same effect on both instars at 0 and $3 \mathrm{~d}$. of the treatment. These treatments caused 100, 100 and 90, $80 \%$ mortality of both $2^{\text {nd }}$ and $4^{\text {th }}$ instar larvae, respectively, as compared to $0 \%$ mortality of control. . Whereas at leaf residues aged 7 and $12 \mathrm{~d}$ Methomyl treatments had higher effect on both instars than that of Pyridalyl. Methomyl caused 80, 70 and $70,60 \%$ mortality for both $2^{\text {nd }}$ and $4^{\text {th }}$ instar larvae, respectively. While, Pyridalyl induced 62, 55 and 40,34\%mortality induced for both instars, respectively, in relative to the check (0\%) as shown in fig. (1) 
Table.1. Residual effect of Pyridalyl and Methomyl against the $2^{\text {nd }}$ and $4^{\text {th }}$ instar of laboratory strain of Spodoptera littoralis larvae at 0, 3, 7 and 12 days after the treatment in relative to control.

\begin{tabular}{|cccccccccc|}
\hline \multirow{2}{*}{ Treatment } & \multicolumn{6}{c|}{$\%$} \\
\cline { 2 - 9 } & \multicolumn{2}{c}{ Zero of Mortality at residues after(Day)treatments } \\
\cline { 2 - 9 } & $\begin{array}{c}\mathbf{2}^{\text {nd }} \\
\text { instar }\end{array}$ & $\begin{array}{c}\mathbf{4}^{\text {th }} \\
\text { instar }\end{array}$ & $\begin{array}{c}\mathbf{2}^{\text {nd }} \\
\text { instar }\end{array}$ & $\begin{array}{c}\mathbf{4}^{\text {th }} \\
\text { instar }\end{array}$ & $\begin{array}{c}\mathbf{2}^{\text {nd }} \\
\text { instar }\end{array}$ & $\begin{array}{c}\mathbf{4}^{\text {th }} \\
\text { instar }\end{array}$ & $\begin{array}{c}\mathbf{2}^{\text {nd }} \\
\text { instar }\end{array}$ & $\begin{array}{c}\mathbf{4}^{\text {th }} \\
\text { instar }\end{array}$ \\
\hline Pyridalyl & 100 & 100 & 90 & 80 & 62 & 55 & 40 & $\mathbf{3 4}$ \\
\hline Methomyl & 100 & 100 & 90 & 80 & 80 & 70 & 70 & $\mathbf{6 0}$ \\
\hline Control & $\mathbf{0}$ & $\mathbf{0}$ & $\mathbf{0}$ & $\mathbf{0}$ & $\mathbf{0}$ & $\mathbf{0}$ & $\mathbf{0}$ & $\mathbf{0}$ \\
\hline
\end{tabular}

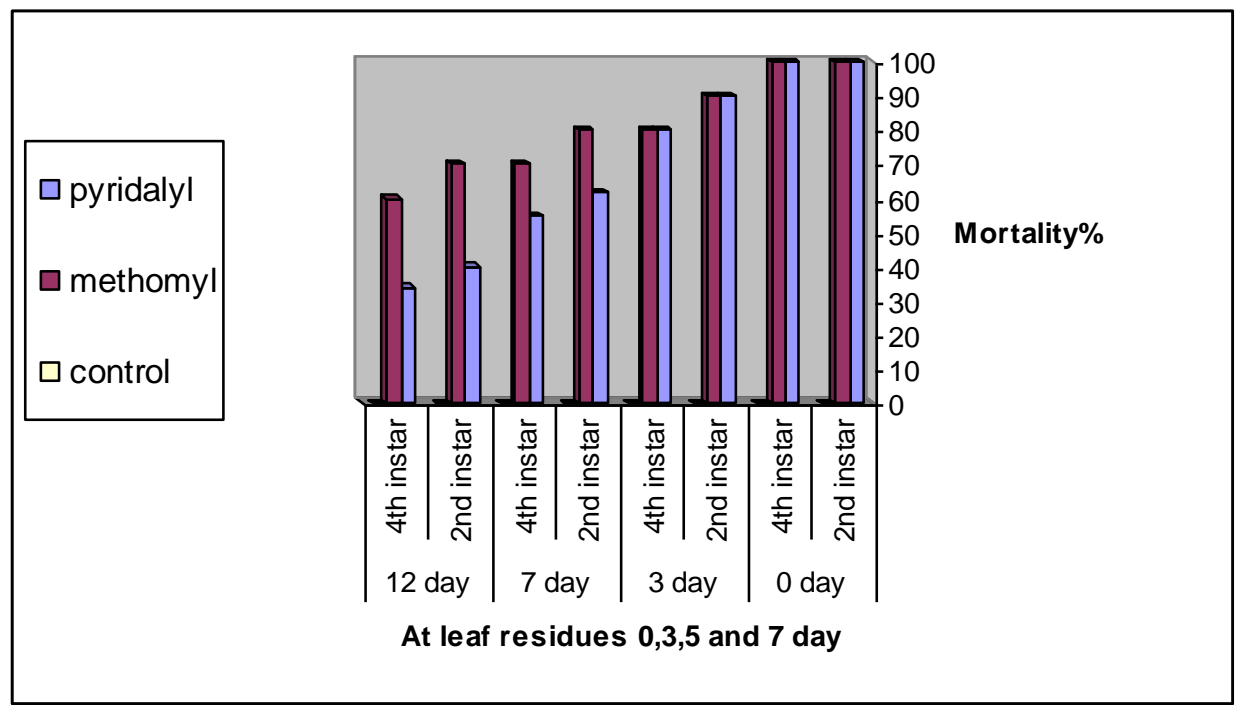

Fig. 1. illustrated the Residual effect of Pyridalyl and Methomyl against the $2^{\text {nd }}$ and $4^{\text {th }}$ instar of laboratory strain of $S$. littoralis larvae at leaf residues aged $0,3,7$ and 12 days, respectively, of the treatment .

The obtained results agree with those obtained by Cook et al. (2004) reported that Indoxacarb, Pyridalyl, Spinosad, methoxyfenozide, and emamectin benzoate controlled beet armyworm, Spodoptera exigua, infestations up to $10 \mathrm{~d}$ after treatment compared to the non-treated control. Also, Ahmed (2004) found that the Spinosad was the most effective compound against the newly hatched larvae of both pink and spiny bollworms after 12 days for laboratory strain, respectively. Khalil and Watson (1986) found that the combinations of organophosphorous insecticides , diflubenzuron with either chlorpyrifos or acephate gave $100 \%$ mortality of S.littoralis larvae after $24 \mathrm{~h}$ of the treatment. They reported that diflubenzuron plus fenvalerate had a long residual effect followed by diflubenzuron plus chlorpyrifos and the residual activity of chlorpyrifos, profenofos and acephate was increased when they applied in 
combination with diflubenzuron. Saad et al. (1977) reported that the synthetic pyrethroid NRDC 147 is $10-100$ times more stable in light than previous pyrethroids when it was tested in the laboratory and field against the Egyptian cotton leafworm Spodoptera littoralis and its residual effect $\left(\mathrm{LT}_{50}\right)$ is more than 7 days while it was 5.8 , 6.8 and 4.2 days for cyolane, leptophos and methamidophos.

\section{Latent effect}

\subsection{Larval and pupal durations}

Data presented in Table $(2,3)$ demonstrated the residual effect of the two tested compounds (pyridalyl and methomyl) reflected the biological activities of $S$. littoralis. The feeding of both $2^{\text {nd }}$ and $4^{\text {th }}$ instar larvae on the leaf residue after 12 days of the two compounds, increased the larval duration. The effect was more pronounced with the $2^{\text {nd }}$ instar treated with both treatments. The larval duration showed highly significant $(p<0.01)$ increase to average 24 and 22days for the two compounds, respectively, as compared to 15days of control ( untreated $2^{\text {nd }}$ instar larvae).Also, the larval treatment of $4^{\text {th }}$ instar with methomyl highly significant( $p<$ 0.01)increased the larval duration to average 17days, as compared to12days of the check. While the fourth instar larvae feeding on Pyridalyl at the same leaf residue (12days) induced less significant increase $(p<0.05)$ in the larval duration to average 16 days in relative to that of the control (12days)

On the other hand, the second and fourth instar larvae feeding on the leaf residues aged $12 d$ of the two compounds highly significant $(p<0.01)$ increased the pupal duration (Table.2,3) of the resulting pupae to average $16.4 \pm 4.3,13.3 \pm 1.3$ and $12 \pm 1.3,13 \pm 2.8$ days of both $2^{\text {nd }}$ and $4^{\text {th }}$ instar larvae treated with Pyridalyl and Methomyl, respectively, as compared to8.2 \pm 0.5 and $7.3 \pm 0.2$ days pupal duration of the resulting pupae from untreated $2^{\text {nd }}$ and $2^{\text {nd }}$ instar larvae of the check.

The obtained results agree with those obtained by Morillo and Notz (2004)found that the duration of the larval and pupal stages and the developmental period from egg to adult of Spodoptera frugiperda was significantly longer in the lambdacyhalotrin-selected strain and the methomyl-selected strain compared to the control strain, from the first to the last generation. Ahmed (2004) who mentioned that the larval period was elongated and the pupal period shorted for the new hatched larvae of pink and spiny bollworms (Laboratory strain) treated with the higher concentrations of Spinosad when compared with untreated larvae 
Table. 2. Latent effect of Pyridalyl and Methomyl against the $2^{\text {nd }}$ instar larvae of the lab. Strain of $S$. littoralis at $12 \mathrm{~d}$. of the treatment in relative to control.

\begin{tabular}{|c|c|c|c|c|c|c|c|}
\hline \multirow[t]{2}{*}{ Treatments } & \multirow{2}{*}{$\begin{array}{l}\text { Larval } \\
\text { periods } \\
\text { (days) } \\
\pm \mathrm{SD}\end{array}$} & \multicolumn{2}{|c|}{$\begin{array}{c}\% \\
\text { Pupation } \\
\pm \text { SD }\end{array}$} & \multirow[t]{2}{*}{$\begin{array}{c}\text { Pupal } \\
\text { duration } \\
\text { days }\end{array}$} & \multirow[t]{2}{*}{$\begin{array}{c}\text { Pupal } \\
\text { weight } \\
\text { mg }\end{array}$} & \multicolumn{2}{|c|}{$\begin{array}{c}\% \text { Moth emergence } \\
\pm S D\end{array}$} \\
\hline & & Normal & Malfo. & & & Normal & Malfo. \\
\hline Pyridalyl & $24 \pm 1 * *$ & $30 \pm 7^{* *}$ & $22.8^{* *}$ & $16.4 \underline{4} 4.3^{* *}$ & $268+43 * *$ & $55 \pm 3.1^{* *}$ & $16^{* *}$ \\
\hline Methomyl & $22 \pm 1.3 * *$ & $10 \pm 4 * *$ & $33.3 * *$ & $13.3 \pm 1.3 * *$ & $303 \pm 33 * *$ & $74 \pm 6 * *$ & $25^{* *}$ \\
\hline Control & $15+0.8$ & 100 & 0 & $8.2 \pm 0.5$ & $507 \pm 3.8$ & 100 & 0 \\
\hline F value & 255.2 & 1097.7 & 1469.5 & 89.158 & 150.001 & 260.1796 & 4078.9 \\
\hline$P$ value & 0.00384 & 0.000230 & 0.000274 & 0.000618 & 0.001445 & 0.000688 & 0.00006 \\
\hline L.S.D. at 0.05 & 2.4 & 9.74 & 3.2 & 3.9 & 63.1 & 7.75 & 2.6 \\
\hline 0.01 & 4.4 & 17.9 & 6 & 7.2 & 115.7 & 14.23 & 6.8 \\
\hline
\end{tabular}

$* *$ = Highly Significant $(p<0.01)$

S.D. =Standard deviation

L.S.D. $=$ Least significant difference

N. S. =none Significant $(p>0.05)$
* Significant $(p<0.05)$

Malfo. $=$ Malformation $\%$

Lab. $=$ Laboratory strain

Table. 3. Latent effect of Pyridalyl and Methomyl against the $4^{\text {th }}$ instar larvae of the lab. Strain of $S$. littoralis at 12 days of the treatment in relative to control.

\begin{tabular}{|c|c|c|c|c|c|c|c|}
\hline \multirow[t]{2}{*}{ Treatments } & \multirow{2}{*}{$\begin{array}{l}\text { Larval } \\
\text { periods } \\
\text { (days) } \\
\pm \mathrm{SD}\end{array}$} & & tion & \multirow{2}{*}{$\begin{array}{c}\text { Pupal } \\
\text { duration } \\
\text { days }\end{array}$} & \multirow{2}{*}{$\begin{array}{c}\text { Pupal } \\
\text { weight } \\
\text { mg }\end{array}$} & \multicolumn{2}{|c|}{$\begin{array}{c}\% \text { Moth emergence } \\
\pm S D\end{array}$} \\
\hline & & Normal & Malfo. & & & Normal & Malfo. \\
\hline Pyridalyl & $16 \pm 2.3 *$ & $60 \pm 7.1^{* *}$ & 4 n.s. & $12 \pm 1.3^{* *}$ & $285+21 * *$ & $60+10 * *$ & 4.3n.s. \\
\hline Methomyl & $17 \pm 0.4 * *$ & $20+14 * *$ & $20 * *$ & $13 \pm 2.8^{* *}$ & $320+104 * *$ & $78+5.6 * *$ & $15^{* *}$ \\
\hline Control & $12 \pm 1.7$ & 100 & 0 & $7.3 \pm 0.2$ & $439+0.9$ & 100 & 0 \\
\hline F value & 24.5 & 236.9 & 24 & 55.1 & 141.6 & 49.6 & 493.96 \\
\hline $\mathrm{P}$ value & 0.029524 & 0.00131 & 0.016277 & 0.005135 & 0.001732 & 0.010 & 0.00020 \\
\hline $\begin{array}{l}\text { L.S.D. at } 0.05 \\
0.01\end{array}$ & $\begin{array}{l}3.85 \\
7.10\end{array}$ & $\begin{array}{l}13.3 \\
23.5\end{array}$ & $\begin{array}{l}12.9 \\
23.9\end{array}$ & $\begin{array}{c}2.2 \\
3.985\end{array}$ & $\begin{array}{l}42.1 \\
77.3\end{array}$ & $\begin{array}{l}14.3 \\
26.1\end{array}$ & $\begin{array}{l}2.2 \\
3.95\end{array}$ \\
\hline
\end{tabular}

$* *$ = Highly Significant $(\mathrm{p}<0.01)$

S.D. =Standard deviation

L.S.D. = Least significant difference

$N$ N. $S=$ none Significant $(p>0.05)$
* Significant $(p<0.05)$

Malfo. $=$ Malformation $\%$

Lab. =Laboratory strain 


\subsection{Pupation and Pupal weight}

Data presented in Table $(2,3)$ showed that the second and fourth instar larvae of $S$. littoralis which fed on the leaf residues aged 12days from treatment with pyridalyl and methomyl highly significant $(p<0.01)$ decreased the pupation percentage in respect to control. The effect was more pronounced with the methomyl treatment, the pupation averaged 10 and $20 \%$ for both $2^{\text {nd }}$ and $4^{\text {th }}$ instar larvae treated with this compound, as compared to $100 \%$ pupation of control. Whereas, the larval feeding of the $2^{\text {nd }}$ instar larvae with pyridalyl on the same leaf residue (12days) had next effect on pupation decrease to reach 30\%pupation, as compared to $60 \%$ pupation of $4^{\text {th }}$ instar larvae treated with pyridalyl, as compared to that of check (100\%).

Likewise, the larval feeding of $2^{\text {nd }}$ and $4^{\text {th }}$ instar larvae on the leaf residues aged 12days of the two tested compounds highly significantly $(p<0.01)$ reduced the pupal weight of the resulting pupae. Pyridalyl was the most suppressive one on the pupal weight, it decreased the pupal weight to average $268 \pm 43$ and $285 \pm 21 \mathrm{mg}$. for pupae treated as $2^{\text {nd }}$ and $4^{\text {th }}$ instar larvae, respectively, as compared to507 \pm 3.8 and $439 \pm 0.9 \mathrm{mg}$ of pupal weight produced from untreated $2^{\text {nd }}$ and $4^{\text {th }}$ instar larvae, respectively. Whereas, the methomyl had the least effect on the pupal weight, it averaged $303 \pm 33$ and $320 \pm 104 \mathrm{mg}$. for pupae treated as $2^{\text {nd }}$ and $4^{\text {th }}$ instar larvae, respectively ,as compared with that of the control(507 \pm 3.8 . and $439 \pm 0.9 \mathrm{mg})$.

The obtained results similar to that obtained by Swelam and Makram (2006) who reported that at different combinations of insecticides, methomyl, carbaryl, esfenvalerate and profenofos used by mixing at the level of LC25 with the ratios of 1 : 2, 1: 1 and 2: 1 against $S$. littoralis appeared significant changes in the pupae weight compared with the control. Also, Ahmed (2004) found that the average of pupation percentages for pink and spiny bollworms gradually decreased with increasing concentrations of the tested compounds (Agerin, Diple $2 x$ Naturalis $L$, Spinosad) in laboratory and field strains, respectively.

\subsection{Moths emergence}

The larval feeding on the leaf residues of the two compounds after 12days of the treatment caused highly significant $(p<0.01)$ decrease on the adult emergence (Table.2, 3). Pyridalyl gave the highest effect in the adult emergence decrease to reached 55 and $60 \%$ for adults produced from treated $2^{\text {nd }}$ and $4^{\text {th }}$ instar larvae, respectively, as compared to $100 \%$ of control. While the larval feeding of the two instar larvae on methomyl recorded 74 and $78 \%$, respectively, of adult emergence in relative to that of the check $(100 \%)$. 
These results are agreement to those obtained Ahmed (2004) who found that adult emergence for pink and spiny bollworms gradually decreased with increasing concentrations of the tested compounds (Agerin , Diple 2x Naturalis L, Spinosad) in laboratory strain.

\subsection{Morphogenetic abnormalities}

Data presented in Table $(2,3)$ demonstrated that the larval feeding of $S$. littoralis on the leaf residues of the two compounds (pyridalyl and methomyl) induced increase in the pupal malformations percentage in relative to control. But the larval treatment of the $2^{\text {nd }}$ and $4^{\text {th }}$ instar larvae with methomyl caused a highly significant $(p<0.01)$ increase in the pupal malformation percentages to reach 33.3 and $20 \%$, for the two instar larvae, respectively, as compared to $0 \%$ of control. Also, Pyridalyl induced highly significant $(p<0.01)$ increase of malformed pupae $(22.8 \%)$ only in case of the treated $2^{\text {nd }}$ instar larvae. Whereas, it was produced non-significant increase (4\%) with the larval treatment of $4^{\text {th }}$ instar, as compared with $0 \%$ of the check.

A similar effect demonstrated with the larval feeding of $S$. littoralis on the leaf residues of the two compounds induced an increase in the adult malformation percentages, as compared to that of the control $(0 \%)$. But the larval treatment of the $2^{\text {nd }}$ and $4^{\text {th }}$ instar larvae with methomyl caused a highly significant $(p<0.01)$ increase in the adult malformation percentages to reach 25 and15\% for the two instar larvae, respectively, as compared to $0 \%$ of control. Also, pyridalyl induced highly significant $(p<0.01)$ increase of malformed adult $(16 \%)$ only in case of the treated $2^{\text {nd }}$ instar larvae. Whereas, it was produced non-significant increase $(4.3 \%)$ with the larval treatment of $4^{\text {th }}$ instar, as compared with $0 \%$ of the check.

Malformations of $S$.littoralis pupae resulting from the larval treatment of the $2^{\text {nd }}$ and $4^{\text {th }}$ instars with pyridalyl in the present work mostly appeared as a larvalpupal intermediates with larval cuticle patches, head capsule and thoracic legs; posterior half of the body has the pupal properties (Fig.1) or undersized pupae: pupae showing body shrinkage (Fig.2).Moreover, moth malformations showing adult malformations often appeared as a moth failed to emerge from the pupal cuticle (Fig.3)or moths with deformed twisted wings and weakly developed body (Figs. 4,5) However, the treatment of $2^{\text {nd }}$ and $4^{\text {th }}$ instars with methomyl ,appeared as larvalpupal monstrosity with larval cuticle, head capsule and thoracic legs; posterior half of the body has the pupal properties (Fig.6) or pupae failed to cast the old cuticle with complete blackening of the body leading to death (Fig.7) and the moth malformations appeared as adult malformations often showing a moth with deformed twisted wings (Fig.8)as compared to normal pupae and adults (Figs.9,10). 
64 COMPARATIVE BIO-RESIDUAL ACTIVITY OF PYRIDALYL AND METHOMY INSECTICIDES AGAINST LARVAE OF THE COTTON LEAFWORM, SPODOPTERA LITTORALIS(BOISD.) 
These results are agreement to those obtained by Javier et al. (2008) demonstrated that Align when administered orally Lobesia botrana gave phenotypic effects included inability to molt properly and deformities Swelam and Makram (2006) who reported that at different combinations of insecticides, methomyl, carbaryl, esfenvalerate and profenofos by mixing at the level of LC25 with the ratios of $1: 2,1$ : 1 and 2: 1 used against $S$. littoralis some malformations in the pupae and moths stages were produced. Also, Ahmed (2004) indicated that Spinosad gave malformed pupal and adults in both laboratory and field strains of both Pink and Spiny bollworms. Solsoloy and Rejesus (1993) mentioned that the crude oils of Jatropha curcas, seed kernel caused production of larval-pupal intermediates and abnormal adults, indicating an insect growth regulatory (IGR) effect.

Table. 4. Latent effect of Pyridalyl and Methomyl against the $2^{\text {nd }}$ instar larvae of the lab. Strain of $S$. littoralis at $12 \mathrm{~d}$. of the treatment in relative to control.

\begin{tabular}{|c|c|c|c|c|c|}
\hline \multirow{2}{*}{ Treatments } & \multirow{2}{*}{$\begin{array}{c}\text { Fecundity } \\
\text { eggs/ f } \\
\text { Mean } \pm \text { S.D. }\end{array}$} & \multirow{2}{*}{$\begin{array}{c}\text { Eggs } \\
\text { hatching \% }\end{array}$} & Longevity & \multicolumn{2}{|c|}{ Adult sex ratio (\%) } \\
\hline & & & Mean \pm S.D. & Male & Female \\
\hline Pyridalyl & $57 \pm 4.7 * *$ & 90 & $7.3 \pm 1.8^{*}$ & 57.1 & 42.9 \\
\hline Methomyl & $0 * *$ & 0 & 7.7 \pm 3.3 n.s. & 33.3 & 66.7 \\
\hline Control & $508+41$ & \multirow[t]{5}{*}{100} & $9+1.9$ & \multirow[t]{5}{*}{50} & \multirow[t]{5}{*}{50} \\
\hline F value & 700.57 & & 8.75 & & \\
\hline$P$ value & 0.001424 & & 0.01601 & & \\
\hline L.S.D. at 0.05 & 75.6 & & 1.7 & & \\
\hline 0.01 & 174.4 & & 2.5 & & \\
\hline \multicolumn{2}{|c|}{$* *=$ Highly Significant $(p<0.01)$} & \multicolumn{4}{|c|}{$*$ Significant $(p<0.05)$} \\
\hline \multicolumn{2}{|c|}{ S.D. =Standard deviation } & \multicolumn{4}{|c|}{ Malfo. = Malformation $\%$} \\
\hline \multicolumn{2}{|c|}{ L.S.D. = Least significant difference } & \multicolumn{4}{|c|}{ Lab. = Laboratory strain } \\
\hline
\end{tabular}

n. $s=$ none Significant $(p>0.05)$ 
Table. 5. Latent effect of Pyridalyl and Methomyl against the $4^{\text {th }}$ instar larvae of the lab. Strain of $S$. littoralis at $12 \mathrm{~d}$. of the treatment in relative to control.

\begin{tabular}{|c|c|c|c|c|c|}
\hline \multirow{2}{*}{ Treatments } & \multirow{2}{*}{$\begin{array}{c}\text { Fecundity } \\
\text { eggs/ f } \\
\text { Mean } \pm \text { S.D. }\end{array}$} & \multirow{2}{*}{$\begin{array}{c}\text { Eggs } \\
\text { hatching } \%\end{array}$} & \multirow{2}{*}{$\begin{array}{c}\begin{array}{c}\text { Longevity } \\
\text { (days) }\end{array} \\
\text { Mean } \pm \text { S.D. }\end{array}$} & \multicolumn{2}{|c|}{ Adult sex ratio (\%) } \\
\hline & & & & Male & Female \\
\hline Pyridalyl & $81+0.8^{* *}$ & 30.1 & $7.9+1.1 * *$ & 43 & 57 \\
\hline Methomyl & $50+8.2 * *$ & 100 & $9.7+0.5^{* *}$ & 40 & 60 \\
\hline Control & $549+34$ & \multirow[t]{5}{*}{100} & $12+1.5$ & \multirow[t]{5}{*}{50} & \multirow[t]{5}{*}{50} \\
\hline F value & 437.91 & & 29.32 & & \\
\hline P value & 0.002362 & & 0.000638 & & \\
\hline L.S.D. at 0.05 & 100.4 & & 1.25 & & \\
\hline 0.01 & 231.8 & & 1.8 & & \\
\hline \multicolumn{2}{|c|}{$* *=$ Highly Significant $(p<0.01)$} & \multicolumn{4}{|c|}{$*$ Significant $(\mathrm{p}<0.05)$} \\
\hline \multicolumn{2}{|c|}{ S.D. =Standard deviation } & \multicolumn{4}{|c|}{ Malfo. = Malformation $\%$} \\
\hline \multicolumn{2}{|c|}{ L.S.D. = Least significant difference } & \multicolumn{4}{|c|}{ Lab. =Laboratory strain } \\
\hline
\end{tabular}

n. $s=$ none Significant $(p>0.05)$

\subsection{Adult fecundity and fertility}

Data presented in Table $(4,5)$ demonstrated that the larval feeding of $S$. littoralis on the leaf residues of the two compounds (pyridalyl and methomyl), highly significant $(p<0.01)$ reduced the adult fecundity in respect of control. While methomyl had the strongest effect on the adult fecundity, it completely inhibited the eggs laying $(0.0)$ in case of the treated $2^{\text {nd }}$ instar larvae, as compared to $508 \pm 41$ eggs/ females of control. While the total number of eggs laid by adult females fed as $4^{\text {th }}$ instar larvae on the methomyl was $50 \pm 8.2$ eggs/ females, as compared to control (549 \pm 34 eggs/ females).On the other hand, the total number of eggs laid by adult females fed as $2^{\text {nd }}$ and $4^{\text {th }}$ instar larvae with pyridalyl was $57 \pm 4.7$ and $81 \pm 0.8$ eggs/ females, as compared to $508 \pm 41$ and $549 \pm 34$ eggs laid by adults produced from untreated $2^{\text {nd }}$ and $4^{\text {th }}$ instar larvae, respectively.

Likewise, the larval feeding of $S$. littoralis on the leaf residues aged12days of the two compounds (pyridalyl and methomyl) reduced the total number of viable eggs laid by adult females fed as $2^{\text {nd }}$ and $4^{\text {th }}$ instar larvae, as compared to control. Also, methomyl had the strongest effect on the eggs hatching, it completely inhibited the eggs laying $(0.0)$ in case of the treated $2^{\text {nd }}$ instar larvae, as compared to $100 \%$ of control. While the methomyl gave none decrease in the total number of viable eggs laid by adults fed as $4^{\text {th }}$ instar(100\%), as compared to control(100\%). On reversely, the larval treatment of $4^{\text {th }}$ instar larvae with pyridalyl had higher effect in depression the total number of viable eggs laid by adult females to reach $30 \%$, as compared to $100 \%$ eggs hatching of control. While, the $2^{\text {nd }}$ instar larvae treated with Pyridalyl 
reduced the eggs hatching of adult females only to $90 \%$, as compared to that of the check (100\%).

These results are agreement to those obtained by Javier et al. (2008) recorded that Align When administered orally, reduced the fecundity and fertility of adults of Lobesia botrana treated with 1,5 , and $10 \mathrm{mg}$ litre-1 and at the highest doses, fecundity and fertility were zero. Also, Pineda et al. (2007)who demonstrated that Spinosad and Methoxyfenozide reduced in a dose-dependent manner the fecundity and fertility of $S$. littoralis adults when treated oral and residually. They reported that the combination of lethal and sublethal effects of methoxy -fenozide and Spinosad might exhibit significant effects on the population dynamics of $S$. littolaris. Likewise, Swelam and Makram (2006) found that some of the mixtures of insecticides, methomyl, carbaryl, esfenvalerate and profenofos at the level of LC25 with the ratios of 1: 2, 1: 1 and 2: 1 against $S$. littoralis showed sterility effect. Also, Morillo and Notz (2004) mentioned that the fertility of eggs of $S$. frugiperda diminished to 50.61 and $47.31 \%$ in the last generation, in the lambdacyhalotrin-selected strain and the methomyl-selected strain, respectively. They indicated that the differences in the duration of some of the insect phases represent a reproductive deterioration in compensation of the survival to the process of selection pressure with the insecticides lambdacyhalotrin and methomyl Solsoloy and Rejesus (1993) reported that the female moths of Helicoverpa amigera that emerged from the larva treated with crude oils derived from the psychic nut, Jatropha curcas, seed showed ovaroles with malformed oocytes such as disintegrated follicular epithelium on atrophid oocytes and the males produced from the treated larvae had few spermatozoa. 


\subsection{Adult longevity}

Data presented in Table(4 and5) showed that feeding of the fourth instar larvae on the leaf residues aged $12 \mathrm{~d}$ sprayed with Pyridalyl and Methomyl highly significant $(p<0.01)$ decreased the adult longevity of $S$. littoralis to average $7.9 a n d 9.7 d$ ,respectively, as compared to $12 \mathrm{~d}$ adult longevity of control. Whereas, the larval treatment of $2^{\text {nd }}$ instar larvae treated with Pyridalyl induced significant $(p<0.05)$ decrease in the adult longevity to average7.3d, as compared to9d that of the check. Whereas, the larval treatment of $2^{\text {nd }}$ instar larvae with Methomyl gave none significant decrease in adult longevity to average7.7d, as compared to control (9d)

These results contracted with those obtained by Javier et al. (2008) recorded that Align When administered orally, longevity of Lobesia botrana adults was not affected. Shadia et al. (2007) who showed that the longevity of exposed male and female of $A$. ipsilon moths was considerably affected by the tested basil oil as well as its active component (eugenol). They reported that the adult male lived longer than adult female and the adult longevities were greatly reduced in case of basil oil as compared with eugenol and control .Also, Morillo and Notz (2004) found that the longevity of males and females of Spodoptera frugiperda only showed differences in some generations in the strains exposed to insecticides

\subsection{Adult sex ratio}

Data in Table (4 and5)indicated that the second and fourth instar larvae of $S$. littoralis fed on the leaf residues sprayed with Pyridalyl and Methomyl shifted the adult sex ratio in respect to that of the control. Methomyl treatment had the strongest effect on the sex ratio .It violent reduced the adult male percentages to reach 33.3 and $40 \%$ for adults emerged from the treated $2^{\text {nd }}$ and $4^{\text {th }}$ instar larvae, respectively, as compared to $50 \%$ of untreated adult males (of both instar). And it increased the adult females to reach 66.6 and $60 \%$ for adults emerged from the treated $2^{\text {nd }}$ and $4^{\text {th }}$ instar larvae, respectively, as compared to50\% of untreated adult females (of both instar). Also, Pyridalyl treatments decreased the adult male' percentages to reach $43 \%$ and increased the adult female percentages to reach $57 \%$ in case of the treated $4^{\text {th }}$ instar, as compared to50\% of control (both males and females). Whereas, the larval treatment of $2^{\text {nd }}$ instar with Pyridalyl had a contract effect of the mentioned effect, it increased the adult males to reach $57.1 \%$, and decreased the adult females to reach $42.9 \%$, as compared to that control (50\%).

\subsection{Conclusion}

The results of the present work demonstrated that the two tested compounds had a similar residual effect against survival of the $2^{\text {nd }}$ and $4^{\text {th }}$ instar larvae of $S$. littoralis at 0 and 3 days of the treatment (they induced 100,100and90,80\%larval 
mortality for both instars treated with both treatments, respectively).While, Methomyl had the greatest effect at 7 and12days compared to Pyridalyl ones. It induced larval mortality reached 80,70 and $70,60 \%$ for the two instars, respectively. While Pyridalyl induced 62,55 and $40,34 \%$ for the two instars, respectively .Pyridalyl toxicity mostly due to inhibition of the cell growth (at0.01 $\mu \mathrm{M}$ ), Shigeru et. al (2005).Therefore, the Methomyl treatment had the strongest effect in pupation depression (to10 and20\%) on larval feeding on leaf residue aged12d. And pupal and adult malformation percentages increase and it had the most potent one in fecundity and eggs hatching (reached 0 ) and play important role in the sex ratio shifting of adult males and females in respect of control. Also, Pyridalyl had the highest effect in pupation pupal weight and adult emergence decrease. Thus, the use of bio-insecticides (of this study) such Pyridalyl may give a high effect of the insect control for a consider period and were safe means maintain the environment and organisms.

\section{REFERENCES}

1. Abbott, W.S. 1925. A method of computing the effectiveness of an insecticide .J.Econ.Entomol. 18: 265-267.

2. Ahmed, E. M. 2004. New approaches for control of cotton bollworms .D .ph thesis, Faculty of Agric. Cairo Univ.

3. Cook D. R., B.R. Leonard and J. Gore. 2004. Field and Laboratory performance of novel insecticides against armyworms (Lepidoptera: Noctuidae). Florida Entomologist 87(4)

4. El-Defrawi, M. F, A. Toppozada, N. Mansour and M. Zaid. 1964. Toxicological studies on the Egyptian cotton leafworm , Prodenia litura J. Econ . Entomol. 57:591-593.

5. Isayama S, S. Saito. , K. Kuroda , K. Umeda , K. Kasamatsu. 2005. Pyridalyl, a novel insecticide: potency and insecticidal selectivity : Arch Insect Biochem Physiol. Apr;58(4):226-33.

6. Javier, F. S.C., M.G Fernando, M.Vicente and P.M Ignacio. 2008. Acute and reproductive effects of Align, an insecticide containing azadirachtin, on the grape berry moth, Lobesia botrana (Lepidoptera: Tortricidae). Journal of Insect Science: Vol. 10, Article 33.

7. Kassem, S. M. I, M. I. Aly, N. S Bakry and M .I Zeid. 1986. Efficacy of methomyl and its mixtures against the Egypt ion cotton leafworm and bollworms. Alexandria. journal.research, 31:3,291-300; 19 ref. 
8. Khalil, F. A and W. M. Watson. 1986. Residual effectiveness of binary mixtures of Dimilin (IGR) with certain insecticides against Spodoptera littoralis (Boise.) larvae, Agricultural-research-review.61:1,99-108;6ref.

9. Mohamed, S.A, N.A.Badr and A. Abd El-Hafez. 2000. Efficacy of two formulations of Pathogenic bacteria Bacillus thurinigiensis against the first instar larvae of Spodoptera littoralis (Boisd.)and Agrotis ipsilon (Hfn.) (LepidopteraNoctuidae).Egypt.J.Agric.Res., 78:(3)1025-1039.

10. Morillo, F. and A. Notz. 2004. Effect of lambdacyhalotrin and methomyl on the biology of Spodoptera frugiperda (Smith) (Lepidoptera: Noctuidae) .Entomotropica (ISSN: 1317-5262) Vol 19 No. 1

11. Pineda ,S., M. I. Schneider , G. Smagghe, A.M. Martinez, P.D.Estal ., E. Viñuela, J. Valle, F. Budia. 2007. Lethal and sublethal effects of methoxyfenozide and Spinosad on Spodoptera littoralis (Lepidoptera: Noctuidae). J Econ Entomol. Jun; 100 (3):773-80.

12. Saad A. S. A., A. A. El-Bahrawi, F. Amin. 1977. A Stable Synthetic Pyrethroid, NRDC 147, and the Control of Spodoptera littoralis . International Journal of Pest Management, Vol. 23, Issue 3 , p. $278-281$.

13. Shadia E, E.A.O. Abd El-Aziz and S. S.Aly. 2007. Chemical composition of Ocimum americanum essential Oil and its Biological Effects against, Agrotis ipsilon, (Lepidoptera: Noctuidae): Research Journal of Agriculture and Biological Sciences, 3(6): 740-747.

14. Shigeru, S.and S.Noriyasu and U. Kimitoshi. 2005. Effects of Pyridalyl, a Novel Insecticidal Agent, on Cultured Sf9 Cells .Journal of Pesticide Science, Vol. 30, No. 1 pp.17-21

15. Shigeru, S., S.Isayama, N. Sakamoto and K. Umeda. 2004. Insecticidal Activity of Pyridalyl: Acute and Sub-Acute Symptoms in Spodoptera litura Larvae. J. Pestic. Sci. Vol. 29, pp.372-375

16. Solsoloy, A.D. and B.M.Rejesus. 1993. Juvenile hormone effect of the insecticidal principle from psychic nut, Jatropha curcas Linn. On cotton bollworm, Helicoverpa armigera (Hubn).Philippines univ. Inc. college, Laguna (Philippines), p.34.received.

17. Swelam, E.S and A.S. Makram. 2006. Joint action of methomyl, carbaryl, esfenvalerate and profenofos and its latent effect on the cotton leafworm,

18. Spodoptera littoralis .J. Pest Cont. \& Environ. Sci. 14 (2): 317 - 331. 


\section{مقارنة الأثر الباقي لمبيدي البيريداليل و الميثوميل ضد يرقات دودة ورق القطن}

\section{الهام فاروق محمود عبد الرحيم}

$$
\text { مركز البحوث الزراعية - معرة بحث وقابة النباتات - الجبزة - الدقي - مصر }
$$

أجريت هذه الدراسة بغرض مقارنة التأثير الحيوي المتبقي لأ ثنين من المركبات: البيريداليل

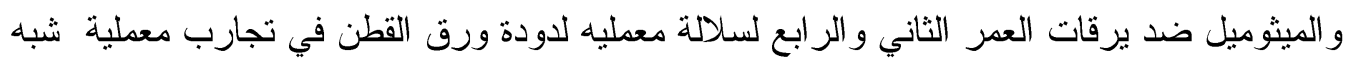

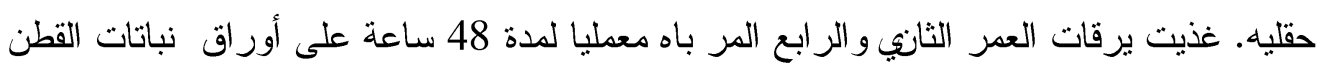

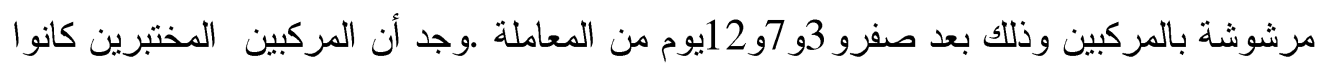

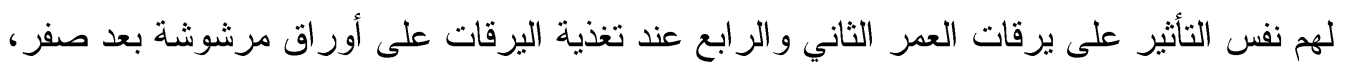

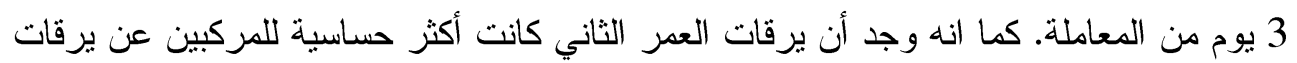

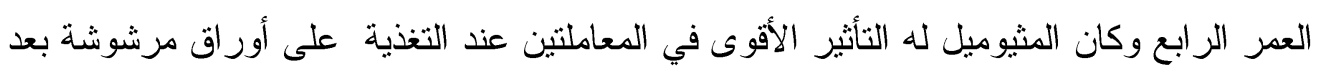

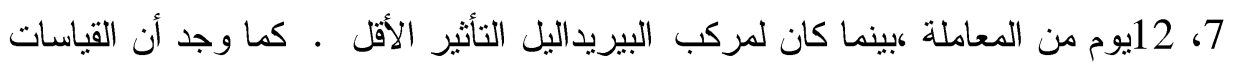

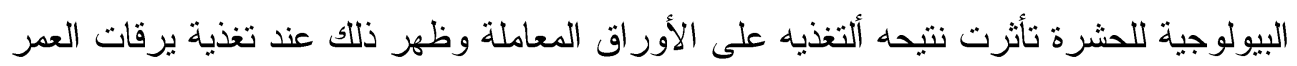
الثاني و الر ابع على أوراق مرشوشة بعد 12 يوم من المعاملة بهذه المركبات كمما وجد أن معاملة

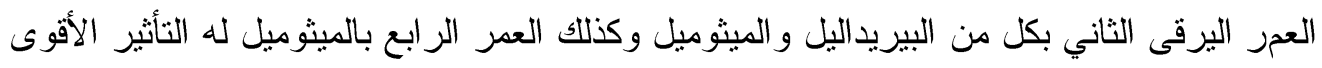

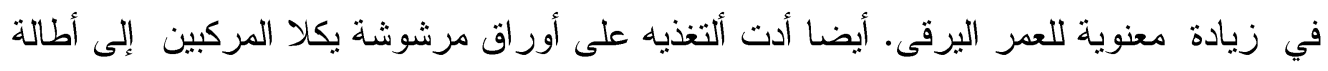

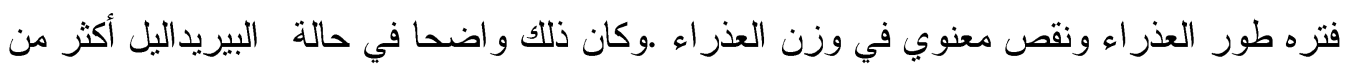

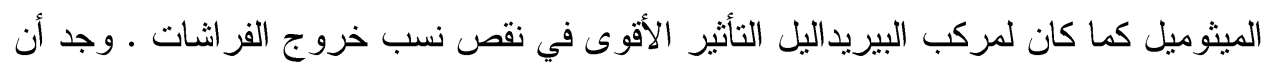

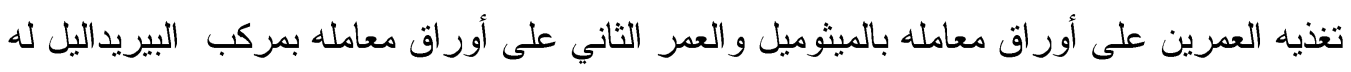

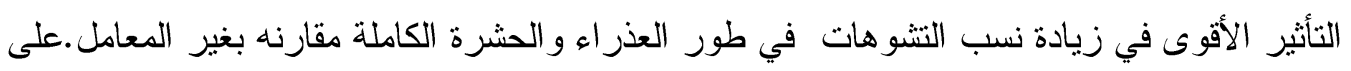
الجانب الآخر وجد أن يرقات العمر الثانى المعاملة بالميثوميل امتلك جهد عالي في انخفاض ولئ واضح

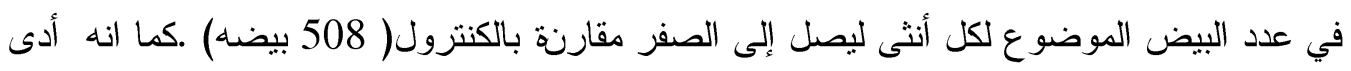

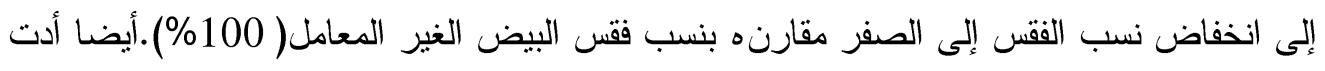

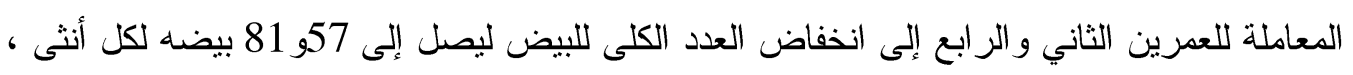

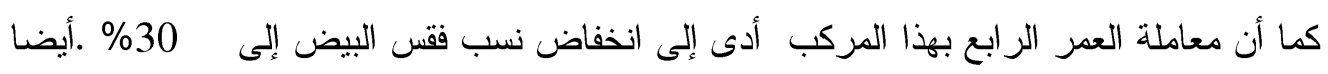

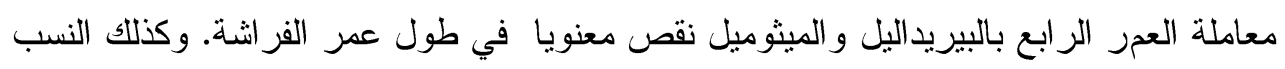

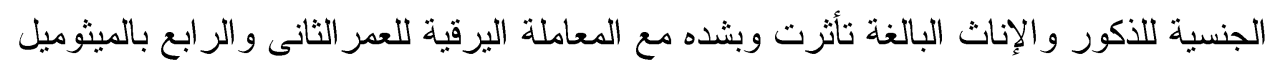

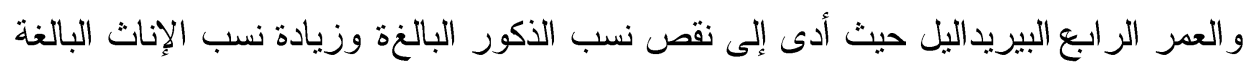

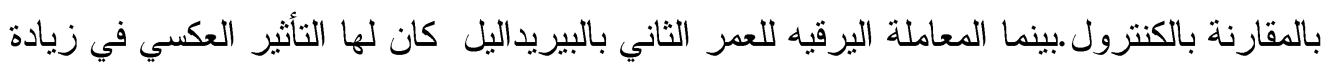

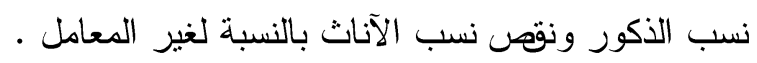

